\title{
Perancangan Aplikasi Sistem Pakar Deteksi Kerusakan Mesin Alat Berat (Beko) Dengan Menerapkan Metode Teorema Bayes
}

\author{
Muhammad Syahrizal $^{1}$, Haryati ${ }^{2}$ \\ ${ }^{1}$ STMIK Budi Darma, Medan, Indonesia \\ ${ }^{2}$ Mahasiswa Program Studi Teknik Informatika, STMIK Budi Darma, Medan, Indonesia
}

\begin{abstract}
Abstrak
Alat berat (beko) atau excavator merupakan alat yang digunakan untuk membantu manusia dalam melakukan pekerjaan pembangunan suatu struktur bangunan. Alat berat (beko) merupakan faktor penting di dalam proyek, terutama proyek-proyek konstruksi maupun pertambangan dan kegiatan lainnya dengan skala yang besar, tapi adakalanya alat seperti ini bisa saja mengalami kerusakan. Kerusakan mesin alat berat (beko) perlu di sistem pakarkan karena tidak semua operator mengetahui atau paham mengenai kerusakan mesin alat berat (beko) atau excavator. Di dalam sistem pakar terdapat metode teorema bayes yang penafsirannya menggunakan dua teorema yang berbeda, teorema ini menjelaskan probabilitas dua kejadian. Atau dapat di artikan teorema ini di gunakan untuk menghitung peluang dalam suatu hipotesa. Dengan demikian alat berat (beko) atau excavator dapat disistem pakarkan menggunakan metode teorema bayes karena dapat menekan biaya operasional agar tidak membengkan dan kegunaan waktu yang efisien.
\end{abstract}

Kata Kunci: Excavator, Sistem Pakar, Teorema Bayes

\begin{abstract}
Heavy equipment or excavator is a tool used to assist human beings in doing the construction work of a building structure. Heavy equipment (beko) is an important factor in the project, especially construction and mining projects and other activities on a large scale, but sometimes such tools can be damaged. Damage machine heavy equipment (beko) needs to be on the system because not all experts know or understand about damage machine heavy equipment (beko) or excavator. In the expert system there is a method of Bayes theorem whose interpretation uses two different theorems, this theorem explaining the probability of two events. Or it can be interpreted this theorem is used to calculate the odds in a hypothesis. Thus, heavy equipment (beko) or excavators can be disistemed using the bayes theorem method because it can reduce operational costs in order not to use and efficient use of time.
\end{abstract}

Keywords: Excavator, Expert System, Bayes Theorem

\section{PENDAHULUAN}

Sistem pakar (expert system) merupakan cabang dari kecerdasan buatan (Artificial Intelligence) dan merupakan bidang ilmu yang muncul seiring perkembangan ilmu komputer saat ini. Sistem ini adalah sistem komputer yang bisa menyamai atau meniru kemampuan seorang pakar. Sistem ini bekerja untuk mengadopsi pengetahuan manusia ke komputer yang menggabungkan dasar pengetahuan (knowledge base) dengan sistem inferensi untuk menggantikan fungsi seorang pakar dalam menyelesaikan suatu masalah [1]. Sistem pakar akan menjadi layaknya seorang pakar di dalam bidang tertentu sesuai kebutuhan manusia. Sistem pakar juga merupakan perkembangan dunia teknologi mutakhir, yang membuat manusia / pengguna mendapatkan informasi dan panduan pada saat yang diperlukan, selain juga dapat menghemat biaya.

Alat berat (beko) merupakan alat yang digunakan untuk membantu manusia dalam melakukan pekerjaan pembangunan suatu struktur bangunan. Alat berat (beko) merupakan faktor penting di dalam proyek, terutama proyek-proyek konstruksi maupun pertambangan dan kegiatan lainnya dengan skala yang besar. Tujuan dari penggunaan alat berat (beko) tersebut adalah untuk memudahkan manusia dalam mengerjakan pekerjaannya, sehingga hasil yang di harapkan dapat tercapai dengan lebih mudah dengan waktu yang relative lebih singkat. Adapun keuntungan-keuntungan dengan menggunakan alat berat (beko) antara lain waktu yang sangat cepat, tenaga yang besar dan nilai-nilai ekonomis. Alat berat (beko) merupakan alat yang sangat penting di masa pembangunan saat ini maka alat ini membutuhkan perawatan ekstra untuk membuatnya terlihat terawat, tapi adakalanya alat seperti ini bisa saja mengalami kerusakan.

Di dalam sistem pakar terdapat beberapa metode seperti, Certainty Factor, Teorema Bayes, Teori Dempster Shaffer, dan lain-lain. Dimana Certainty Factor adalah suatu metode untuk membuktikan apakah suatu fakta itu pasti ataukah tidak pasti yang berbentuk metric yang biasanya di gunakan dalam sistem pakar. Teorema Bayes adalah teorema yang digunakan untuk menghitung peluang dalam suatu hipotesa. Teori Dempster Shaffer adalah suatu teori matematika untuk membuktikan berdasarkan belief functions and plausible (fungsi kepercayaan dan pemikiran yang masuk akal), yang di gunakan untuk mengkombinasikan potongan informasi yang terpisah (bukti) 
untuk mengkalkulasi kemungkinan dari suatu peristiwa. Untuk memecahkan masalah yang ada kali ini penulis akan membahasnya dengan metode Teorema Bayes.

\section{TEORITIS}

\subsection{Sistem Pakar}

Kecerdasan buatan adalah suatu ilmu yang mempelajari cara membuat komputer melakukan sesuatu seperti yang di lakukan oleh manusia. Definisi lain yaitu kecerdasan buatan (artificial intelligence) merupakan kawasan penelitian, aplikasi dan instruksi yang terkait dengan pemograman komputer untuk melakukan sesuatu hal yang dalam pandangan manusia adalah cerdas. Kecerdasan buatan (AI) sebagai sebuah studi tentang bagaimana membuat komputer melakukan hal-hal yang pada saat ini dapat di lakukan lebih baik oleh manusia [2].

Sistem pakar (expert system) merupakan cabang dari kecerdasan buatan (Artificial Intelligence) dan merupakan bidang ilmu yang muncul seiring perkembangan ilmu komputer saat ini. Sistem ini adalah sistem komputer yang bisa menyamai atau meniru kemampuan seorang pakar. Sistem ini bekerja untuk mengadopsi pengetahuan manusia ke komputer yang menggabungkan dasar pengetahuan (knowledge base) dengan sistem inferensi untuk menggantikan fungsi seorang pakar dalam menyelesaikan suatu masalah [1].

Adapun ciri-ciri sistem pakar adalah sebagai berikut:

1. Terbatas pada bidang yang spesifik.

2. Dapat memberikan penalaran untuk data-data yang tidak lengkap atau tidak pasti.

3. Dapat mengemukakan rangkaian alasan yang di berikannya dengan cara yang dapat di pahami.

4. Berdasarkan pada rule atau kaidah tertentu.

5. Dirancang untuk dapat di kembangkan secara bertahap.

6. Outputnya bersifat nasihat atau anjuran.

7. Output tergantung dari dialog dengan user.

8. Knowledge base dan inferensi engine terpisah [1].

\subsection{Excavator}

Excavator di pergunakan pada pekerjaan konstruksi, kehutanan dan industri pertambangan, karena alat ini dapat melakukan berbagai macam pekerjaan. Pekerjaan yang di lakukan di antaranya untuk penggalian parit sempit sebelum meletakkan pipa atau penggali parit untuk pondasi bangunan, mengisi material ke dalam truk atau jenis alat pengangkut lain, penggalian untuk memindahkan material dari suatu area dan menempatkannya ke tempat lain, menghancurkan dinding beton, memotong baja, memindahkan material di tempat pembuangan, melakukan pengeboran tanah, menghancurkan batu, mengambil lumpur dan pasir dari sungai, mendorong material dan beragai pekerjaan lainnya. Pekerjaan tersebut diatas tergantung pada worktool yang digunakan.

Excavator dapat bekerja dalam kondisi basah tanpa adanya masalah pada permukaan yang keras. Namun jika permukaan lunak, kondisi basah akan menyebabkan bagian depan track tenggelam. Seluruh Excavator besar caterpillar menggunakan track dan yang berukuran kecil dapat menggunakan roda ataupun track.

Deteksi merupakan suatu keingintahuan manusia dalam suatu hal tertentu yang menyebabkan adanya pembuatan alat yang dapat membantu memecahkan masalah keingintahuan manusia. Dengan adanya alat deteksi atau perancangan alat deteksi mampu menghasikan informasi yang menjadi penyebab tersebut atau yang menjadi gejala-gejala pada kerusankan tersebut. Deteksi dalam bidang teknik mampu membantu mengetahui kerusakan pada suatu alat. Deteksi dapat di artikan dengan diagnosis atau diagnosa di dalam bidang kesehatan. Diagnosa yang dimaksud adalah untuk mengetahui gejala-gejala kerusakan atau menentukan tingkatan kerusakan pada alat berat (excavator).

Adapun jenis-jenis kerusakan mesin alat berat (beko) adalah sebagai berikut:

1. hard to start,

2. kerusakan electrical system dan

3. kerusakan air intake and exhaust system.

4. kerusakan pada fuel system

\subsection{Teorema Bayes}

Teorema bayes di kemukakan oleh seorang pendeta Presbyterian inggris pada tahun 1763 yang bernama Thomas Bayes. Theorema bayes kemudian di sempurnakan oleh laplace. Theorema bayes di gunakan untuk menghitung probabilitas terjadinya suatu peristiwa berdasarkan pengaruh yang di dapat dari hasil observasi.

Teorema Bayes, diambil dari nama Rev.Thomas Bayes, menggambarkan hubungan antara peluang bersyarat dari dua kejadian $H$ dan $E$ sebagai berikut: 


$$
P(H \backslash E)=\frac{\mathrm{P}(\mathrm{E} \backslash \mathrm{H}) \cdot \mathrm{P}(\mathrm{H})}{\mathrm{P}(\mathrm{E})}
$$

Keterangan:

\begin{tabular}{|l|l|}
\hline $\mathrm{P}(\mathrm{H} \backslash \mathrm{E})$ & Probabilitas hipotesis $\mathrm{H}$ terjadi jika evidence $\mathrm{E}$ terjadi \\
\hline $\mathrm{P}(\mathrm{E} \backslash \mathrm{H})$ & Probabilitas munculnya evidence $\mathrm{E}$, jika hipotesa $\mathrm{H}$ terjadi \\
\hline $\mathrm{P}(\mathrm{H})$ & Probabilitas hipotesis $\mathrm{H}$ tanpa memandang evidence apapun \\
\hline $\mathrm{P}(\mathrm{E})$ & Probabilitas evidence $\mathrm{E}$ tanpa memandang apapun \\
\hline
\end{tabular}

\section{ANALISA DAN PEMBAHASAN}

Alat berat (beko) merupakan alat yang digunakan untuk membantu manusia dalam melakukan pekerjaan pembangunan suatu struktur bangunan. Alat berat (beko) merupakan faktor penting di dalam proyek, terutama proyek-proyek konstruksi maupun pertambangan dan kegiatan lainnya dengan skala yang besar. Tujuan dari penggunaan alat berat (beko) tersebut adalah untuk memudahkan manusia dalam mengerjakan pekerjaannya, sehingga hasil yang di harapkan dapat tercapai dengan lebih mudah dengan waktu yang relative lebih singkat. Adapun keuntungan-keuntungan dengan menggunakan alat berat (beko) antara lain waktu yang sangat cepat, tenaga yang besar dan nilai-nilai ekonomis. Alat berat (beko) merupakan alat yang sangat penting di masa pembangunan saat ini maka alat ini membutuhkan perawatan ekstra untuk membuatnya terlihat terawat, tapi adakalanya alat seperti ini bisa saja mengalami kerusakan.

Kerusakan mesin alat berat (beko) perlu di sistem pakarkan karena tidak semua operator mengetahui atau paham mengenai kerusakan mesin alat berat (beko). Dengan demikian operator harus mendatangkan pakarnya atau untuk bertanya langsung dengan pakarnya, dengan adanya sistem pakar dapat membantu operator atau masyarakat awam yang ingin mengetahui kerusakan mesin alat berat (beko) tanpa harus bertatap muka langsung dengan ahlinya atau pakarnya. Kerusakan mesin alat berat (beko) bisa saja terjadi secara tiba-tiba karena kurangnya keperawatan. Akibatnya dari kerusakan mesin alat berat beko ini mengakibatkan ongkos biaya perbaikan membengkak atau membuat biaya pengeluaran menjadi bertambah, dan karena mengharuskan mendatangkan pakarnya langsung ke lokasi kejadian yang membutuhkan waktu yang membuat pekerjaan tertunda atau sampai tidak bisa bekerja karena alat tidak bisa di pakai, dan akan membuat proyek bisa saja rugi karena menunggu pakar datang yang membuat proyek tidak bekerja.

Dalam contoh kasus kerusakan mesin alat berat (beko) misalnya sebuah mesin alat berat (beko) mengalami kerusakan tetapi operator tidak tahu apa penyebab kenapa mesin alat berat (beko) tersebut bisa mengalami kerusakan.

Dalam kasus diatas penulis akan menguraikan penyelesaian permasalahan kerusakan mesin alat berat (beko) dengan menerapkan pengerjaan dengan metode teorema bayes.

Jika mesin alat berat beko mengalami kerusakan, maka yang pertama kali dilakukan adalah mengetahui gejalagejala yang di rasakan.

Tabel 1. Gejala-Gejala Kerusakan Mesin Alat Berat (Beko)

\begin{tabular}{|c|c|c|c|}
\hline $\mathrm{No}$ & Kerusakan & Kode & Gejala \\
\hline \multirow{8}{*}{1.} & \multirow{8}{*}{ Kerusakan hard to start } & G1 & Voltage battery terlalu rendah \\
\hline & & $\mathrm{G} 2$ & Kabel atau swich putus \\
\hline & & G3 & Dinamo starter sudah pendek atau habis \\
\hline & & G4 & Bahan bakar solar habis \\
\hline & & G5 & Filter solar kotor \\
\hline & & G6 & Fuel pump broken \\
\hline & & G7 & Injector tersumbat \\
\hline & & G8 & Element filter kotor \\
\hline \multirow{3}{*}{2.} & \multirow{3}{*}{$\begin{array}{l}\text { Kerusakan pada } \\
\text { electrical system }\end{array}$} & G01 & Wiring harness tidak terhubung ke battery \\
\hline & & G02 & $\begin{array}{l}\text { Starting switch tidak mengalirkan arus listrik ke } \\
\text { penggerak relay utama }\end{array}$ \\
\hline & & G03 & $\begin{array}{l}\text { Starting motor tidak dapat merubah tenaga listrik } \\
\text { menjadi tenaga putar }\end{array}$ \\
\hline
\end{tabular}




\begin{tabular}{|c|c|c|c|}
\hline No & Kerusakan & Kode & Gejala \\
\hline \multirow{3}{*}{3.} & \multirow{3}{*}{$\begin{array}{l}\text { Kerusakan pada air } \\
\text { intake and exhaust } \\
\text { system }\end{array}$} & GA1 & Turbocharge tidak bisa memompa udara \\
\hline & & GA2 & Aftercooler tidak bisa mendinginkan udara \\
\hline & & GA3 & Tidak terjadinya pembakaran diruang pembakaran \\
\hline \multirow{3}{*}{4.} & \multirow{3}{*}{$\begin{array}{l}\text { Kerusakan pada fuel } \\
\text { system }\end{array}$} & GB1 & $\begin{array}{l}\text { Terjadi kebocoran pada sambungan antara hose } \\
\text { ataupun piping dari fuel line. }\end{array}$ \\
\hline & & GB2 & terjadi kebocoran fada fuel filter. \\
\hline & & GB3 & selenoid injector tidak bekerja. \\
\hline
\end{tabular}

Dari tabel diatas dapat dilihat gejala-gejala dari kerusakan mesin alat berat (beko), maka setelah itu penulis memasukan bobot atau termonologi kepastian dari gejala yang ada, tabel termonologi dapat dilihat pada tabel 3.2 di bawah ini.

Tabel 2. Nilai Bayes

\begin{tabular}{|c|c|}
\hline Terminologi Kepastian & A/B \\
\hline Tidak Pasti & 0 \\
\hline Tidak Tahu & 0,2 \\
\hline Kurang Pasti & 0,4 \\
\hline Cukup Pasti & 0,6 \\
\hline Hampir Pasti & 0,8 \\
\hline Pasti & 1,0 \\
\hline
\end{tabular}

Sebagai contoh proses pemberian bobot pada setiap premis (gejala) hingga memperoleh persentase keyakinan untuk mengidentifikasi gejala kerusakan mesin alat berat (beko).

Tabel 3. Tabel Persentase Kesimpulan

\begin{tabular}{|c|c|}
\hline $\begin{array}{c}\text { Tingkat } \\
\text { persentase }\end{array}$ & Nilai Keyakinan \\
\hline $0 \%-50 \%$ & $\begin{array}{c}\text { Sedikit kemungkinan atau } \\
\text { kemungkinan kecil }\end{array}$ \\
\hline $51 \%-79 \%$ & Kemungkinan \\
\hline $80 \%-99 \%$ & Kemungkinan Besar \\
\hline $100 \%$ & Sangat yakin \\
\hline
\end{tabular}

Dalam hal ini Pakar menentukan nilai Bayes unuk masing-masing ciri-ciri sebagai berikut :

Tabel 4. Tabel Pakar Menentukan Nilai Teorema Bayes

\begin{tabular}{|c|c|c|c|c|c|}
\hline No & Kerusakan & Kode & Gejala & Bobot & Keterangan \\
\hline \multirow{6}{*}{1.} & \multirow{6}{*}{$\begin{array}{l}\text { Kerusakan } \\
\text { hard to start }\end{array}$} & G1 & Voltage battery terlalu rendah & 0,8 & Hampir pasti \\
\hline & & G2 & Kabel atau swich putus & 0,6 & Cukup pasti \\
\hline & & G3 & Dinamo starter sudah pendek atau habis & 0,6 & Cukup pasti \\
\hline & & G4 & Bahan bakar solar habis & 0,8 & Hampir pasti \\
\hline & & G5 & Filter solar kotor & 0,6 & Cukup pasti \\
\hline & & G6 & Fuel pump broken & 0,6 & Cukup pasti \\
\hline
\end{tabular}




\begin{tabular}{|c|c|c|c|c|c|}
\hline No & Kerusakan & Kode & Gejala & Bobot & Keterangan \\
\hline & & G7 & Injector tersumbat & 0,4 & Kurang pasti \\
\hline & & G8 & Element filter kotor & 0,6 & Cukup pasti \\
\hline \multirow{3}{*}{2.} & \multirow{3}{*}{$\begin{array}{l}\text { Kerusakan } \\
\text { pada } \\
\text { electrical } \\
\text { system }\end{array}$} & G01 & Wiring harness tidak terhubung ke battery & 0,6 & Cukup pasti \\
\hline & & G02 & $\begin{array}{l}\text { Starting switch tidak mengalirkan arus listrik } \\
\text { ke penggerak relay utama }\end{array}$ & 0,6 & Cukup pasti \\
\hline & & G03 & $\begin{array}{l}\text { Starting motor tidak dapat mengubah tenaga } \\
\text { listrik menjadi tenaga putar }\end{array}$ & 0,8 & Hampir pasti \\
\hline \multirow{3}{*}{3.} & \multirow{3}{*}{$\begin{array}{l}\text { Kerusakan } \\
\text { pada air } \\
\text { intake and } \\
\text { exhaust } \\
\text { system }\end{array}$} & GA1 & Turbocharge tidak bisa memompa udara & 0,6 & Cukup pasti \\
\hline & & GA2 & Aftercooler tidak bisa mendinginkan udara & 0,6 & Cukup pasti \\
\hline & & GA3 & $\begin{array}{l}\text { Tidak terjadinya pembakaran di dalam ruang } \\
\text { bakar }\end{array}$ & 0,8 & Hampir pasti \\
\hline \multirow{3}{*}{4.} & \multirow{3}{*}{$\begin{array}{l}\text { Kerusakan } \\
\text { pada fuel } \\
\text { system }\end{array}$} & GB1 & $\begin{array}{l}\text { Terjadi kebocoran pada sambungan antara } \\
\text { hose ataupun piping dari fuel line. }\end{array}$ & 0,6 & Cukup Pasti \\
\hline & & GB2 & Terjadi kebocoran fada fuel filter. & 0,4 & Kurang Pasti \\
\hline & & BG3 & selenoid injector tidak bekerja & 0,6 & Cukup Pasti \\
\hline
\end{tabular}

Misalkan user memilih jawaban sebagai berikut :

Tabel 5. Tabel User Memilih Jawaban

\begin{tabular}{|c|c|c|c|c|c|}
\hline No & Kerusakan & Kode & Gejala & $\begin{array}{c}\text { Bobot } \\
\text { keyakinan }\end{array}$ & Keterangan \\
\hline \multirow{8}{*}{1.} & \multirow{8}{*}{$\begin{array}{l}\text { Kerusakan hard } \\
\text { to start }\end{array}$} & G1 & Voltage battery terlalu rendah & 0,6 & Cukup pasti \\
\hline & & G2 & Kabel atau swich putus & 0,4 & Kurang pasti \\
\hline & & G3 & $\begin{array}{l}\text { Dinamo starter sudah pendek atau } \\
\text { habis }\end{array}$ & 0,2 & Tidak tahu \\
\hline & & $\mathrm{G} 4$ & Bahan bakar solar habis & 0,6 & Cukup pasti \\
\hline & & G5 & Filter solar kotor & 0,2 & Tidak tahu \\
\hline & & G6 & Fuel pump broken & 0,2 & Tidak tahu \\
\hline & & G7 & Injector tersumbat & 0,2 & Tidak tahu \\
\hline & & G8 & Element filter kotor & 0,2 & Tidak tahu \\
\hline \multirow{3}{*}{2.} & \multirow{3}{*}{$\begin{array}{l}\text { Kerusakan pada } \\
\text { electrical system }\end{array}$} & G01 & $\begin{array}{l}\text { Wiring harness tidak terhubung ke } \\
\text { battery }\end{array}$ & 0,2 & Tidak tahu \\
\hline & & G02 & $\begin{array}{l}\text { Starting switch tidak mengalirkan } \\
\text { arus listrik ke penggerak relay } \\
\text { utama }\end{array}$ & 0,4 & Kurang pasti \\
\hline & & G03 & $\begin{array}{l}\text { Starting motor tidak dapat } \\
\text { mengubah tenaga listrik menjadi } \\
\text { tenaga putar }\end{array}$ & 0,6 & Cukup pasti \\
\hline \multirow{3}{*}{3.} & \multirow{3}{*}{$\begin{array}{l}\text { Kerusakan pada } \\
\text { air intake and } \\
\text { exhaust system }\end{array}$} & G001 & $\begin{array}{l}\text { Turbocharge tidak bisa memompa } \\
\text { udara }\end{array}$ & 0,2 & Tidak tahu \\
\hline & & G002 & $\begin{array}{l}\text { Aftercooler tidak bisa } \\
\text { mendinginkan udara }\end{array}$ & 0,2 & Tidak tahu \\
\hline & & G003 & $\begin{array}{l}\text { Tidak terjadinya pembakaran } \\
\text { didalam ruang bakar }\end{array}$ & 0,6 & Cukup pasti \\
\hline
\end{tabular}




\begin{tabular}{|c|c|c|c|c|c|}
\hline No & Kerusakan & Kode & Gejala & $\begin{array}{c}\text { Bobot } \\
\text { keyakinan }\end{array}$ & Keterangan \\
\hline \multirow[t]{3}{*}{4.} & \multirow[t]{3}{*}{$\begin{array}{l}\text { Kerusakan pada } \\
\text { fuel system }\end{array}$} & GB1 & $\begin{array}{l}\text { Terjadi kebocoran pada sambungan } \\
\text { antara hose ataupun piping dari fuel } \\
\text { line. }\end{array}$ & 0,2 & Tidak tahu \\
\hline & & GB2 & Terjadi kebocoran fada fuel filter. & 0,2 & Tidak tahu \\
\hline & & BG3 & selenoid injector tidak bekerja & 0,4 & Kurang pasti \\
\hline
\end{tabular}

Dalam mengekspresikan derajat peluang, Teorema Bayes untuk mengasumsikan derajat peluang seorang pakar terhadap suatu data dengan mengalihkan Teorema Bayes bobot kepastian dengan Teorema Bayes dengan kerusakan hard to start adalah sebagai berikut:

$$
\begin{aligned}
& P[H] 1=\frac{\mathrm{H} 1}{\mathrm{H} 1+\mathrm{H} 2+\mathrm{H} 3+\mathrm{H} 4+\mathrm{H} 5+\mathrm{H} 6+\mathrm{H} 7+\mathrm{H} 8} \\
& =\frac{0,8}{5} \\
& =0,16 \\
& P[H] 2=\frac{\mathrm{H} 2}{\mathrm{H} 1+\mathrm{H} 2+\mathrm{H} 3+\mathrm{H} 4+\mathrm{H} 5+\mathrm{H} 6+\mathrm{H} 7+\mathrm{H} 8} \\
& =\frac{0,6}{5} \\
& =0,12 \\
& P[H] 3=\frac{\mathrm{H} 3}{\mathrm{H} 1+\mathrm{H} 2+\mathrm{H} 3+\mathrm{H} 4+\mathrm{H} 5+\mathrm{H} 6+\mathrm{H} 7+\mathrm{H} 8} \\
& =\frac{0,6}{5} \\
& =0,12 \\
& P[H] 4=\frac{\mathrm{H} 4}{\mathrm{H} 1+\mathrm{H} 2+\mathrm{H} 3+\mathrm{H} 4+\mathrm{H} 5+\mathrm{H} 6+\mathrm{H} 7+\mathrm{H} 8} \\
& =\frac{0,8}{5} \\
& =0,16 \\
& P[H] 5=\frac{\mathrm{H} 5}{\mathrm{H} 1+\mathrm{H} 2+\mathrm{H} 3+\mathrm{H} 4+\mathrm{H} 5+\mathrm{H} 6+\mathrm{H} 7+\mathrm{H} 8} \\
& =\frac{0,6}{5} \\
& =0,12 \\
& P[H] 6=\frac{\mathrm{H} 6}{\mathrm{H} 1+\mathrm{H} 2+\mathrm{H} 3+\mathrm{H} 4+\mathrm{H} 5+\mathrm{H} 6+\mathrm{H} 7+\mathrm{H} 8} \\
& =\frac{0,6}{5} \\
& =0,12 \\
& P[H] 7=\frac{\mathrm{H} 7}{\mathrm{H} 1+\mathrm{H} 2+\mathrm{H} 3+\mathrm{H} 4+\mathrm{H} 5+\mathrm{H} 6+\mathrm{H} 7+\mathrm{H} 8} \\
& =\frac{0,4}{5} \\
& =0,08 \\
& P[H] 8=\frac{\mathrm{H} 8}{\mathrm{H} 1+\mathrm{H} 2+\mathrm{H} 3+\mathrm{H} 4+\mathrm{H} 5+\mathrm{H} 6+\mathrm{H} 7+\mathrm{H} 8} \\
& =\frac{0,6}{5} \\
& =0,12
\end{aligned}
$$

Setelah nilai $\mathrm{P}(\mathrm{Hi})$ diketahui, probabilitas hipotesis $\mathrm{H}$ tanpa memandang Evidence apapun, maka langkah selanjutnya adalah: 


$$
\begin{aligned}
\sum_{k=1}^{n} & =\mathrm{P}(\mathrm{Hi}) * \mathrm{P}(\mathrm{E} \backslash \mathrm{Hi}-\mathrm{n}) \\
\sum_{k=1}^{8} & =0,16 * 0,6+0,12 * 0,4+0,12 * 0,2+0,16 * 0,6+0,12 * 0,2+0,12 * 0,2+0,08 * 0,2+0,12 * 0,2 \\
& =0,096+0,048+0,024+0,096+0,024+0,024+0,016+0,024 \\
& =0,352
\end{aligned}
$$

Langkah selanjutnya adalah mencari nilai $\mathrm{P}(\mathrm{HilE})$ atau probabilitas hipotesis Hi benar jika diberikan evidence $\mathrm{E}$.

$$
\begin{aligned}
& \mathrm{P}(H i \mid E)=\frac{P(E \backslash H i) * P(H i)}{\sum_{k=1}^{n} P(E \backslash H i) * P(H i)} \\
& \mathrm{P}(H 1 \mid E)=\frac{0,6 * 0,16}{0,352}=0,2727 \\
& \mathrm{P}(H 2 \mid E)=\frac{0,4 * 0,12}{0,352}=0,1364 \\
& \mathrm{P}(H 3 \mid E)=\frac{0,2 * 0,12}{0,352}=0,0682 \\
& \mathrm{P}(H 4 \mid E)=\frac{0,6 * 0,16}{0,352}=0,2727 \\
& \mathrm{P}(H 5 \mid E)=\frac{0,2 * 0,12}{0,352}=0,0682 \\
& \mathrm{P}(H 6 \mid E)=\frac{0,2 * 0,12}{0,352}=0,0682 \\
& \mathrm{P}(H 7 \mid E)=\frac{0,2 * 0,08}{0,352}=0,0454 \\
& \mathrm{P}(H 8 \mid E)=\frac{0,2 * 0,12}{0,352}=0,0682
\end{aligned}
$$

Setelah seluruh nilai $\mathrm{P}(\mathrm{Hi} \backslash \mathrm{E})$ diketahui, maka jumlahkan seluruh nilai bayesnya dengan rumus sebagai berikut:

$$
\begin{aligned}
\sum_{k=1}^{n} \text { Bayes } & =\text { Bayes } 1+\text { Bayes } 2+\text { Bayes } 3+\text { Bayes } 4+\text { Bayes } 5+\text { Bayes }+ \text { Bayes } 7+\text { Bayes } 8 \\
& =0,2727+0,1364+0,0682+0,2727+0,0682+0,0682+0,0454+0,0682 \\
& =1
\end{aligned}
$$

Dari kesimpulan perhitungan diatas maka dapat dipastikan Alat berat (beko) diprediksi mengalami hard to start dengan nilai $100 \%$ maka solusinya adalah periksa kondisi battery, charge battery atau ganti jika perlu dan mengisi bahan bakar solar. Pengerjaan kerusakan electrical system dengan kaidah tersebut kemudian dihitung nilai Teorema Bayes nya dengan mengalihkan Teorema Bayes bobot kepastian dengan Teorema Bayes menjadi:

$$
\begin{aligned}
P[H] 1= & \frac{\mathrm{H} 1}{\mathrm{H} 1+\mathrm{H} 2+\mathrm{H} 3} \\
& =\frac{0,6}{2} \\
& =0,3 \\
P[H] 2= & \frac{\mathrm{H} 2}{\mathrm{H} 1+\mathrm{H} 2+\mathrm{H} 3} \\
& =\frac{0,6}{2} \\
& =0,3 \\
P[H] 3 & =\frac{\mathrm{H} 3}{\mathrm{H} 1+\mathrm{H} 2+\mathrm{H} 3} \\
& =\frac{0,8}{2} \\
& =0,4
\end{aligned}
$$


Setelah nilai $\mathrm{P}(\mathrm{Hi})$ diketahui, probabilitas hipotesis $\mathrm{H}$ tanpa memandang Evidence apapun, maka langkah selanjutnya adalah:

$$
\begin{aligned}
\sum_{k=1}^{n} & =\mathrm{P}(\mathrm{Hi}) * \mathrm{P}(\mathrm{E} \backslash \mathrm{Hi}-\mathrm{n}) \\
\sum_{k=1}^{3}= & 0,3 * 0,2+0,3 * 0,4+0,4 * 0,6 \\
& =0,06+0,12+0,24 \\
& =0,42
\end{aligned}
$$

Langkah selanjutnya adalah mencari nilai $\mathrm{P}(\mathrm{HilE})$ atau probabilitas hipotesis Hi benar jika diberikan evidence $\mathrm{E}$.

$$
\begin{aligned}
& \mathrm{P}(H i \mid E)=\frac{P(E \backslash H i) * P(H i)}{\sum_{k=1}^{n} P(E \backslash H i) * P(H i)} \\
& \mathrm{P}(H 1 \mid E)=\frac{0,2 * 0,3}{0,42}=0,1428 \\
& \mathrm{P}(H 2 \mid E)=\frac{0,4 * 0,3}{0,42}=0,2857 \\
& \mathrm{P}(H 3 \mid E)=\frac{0,6 * 0,4}{0,42}=0,5714
\end{aligned}
$$

Setelah seluruh nilai $\mathrm{P}(\mathrm{HilE})$ diketahui, maka jumlahkan seluruh nilai bayesnya dengan rumus sebagai berikut:

$$
\begin{aligned}
\sum_{k=1}^{n} \text { Bayes }= & \text { Bayes } 1+\text { Bayes } 2+\text { Bayes } 3 \\
& =0,1428+0,2857+0,5714 \\
& =0,9999
\end{aligned}
$$

Dari kesimpulan perhitungan diatas maka dapat dipastikan Alat berat (beko) diprediksi mengalami kerusakan electrical system dengan nilai 99,99\% maka solusinya adalah periksa kondisi starting motor hingga menyala atau ganti jika perlu. Pengerjaan kerusakan air intake and exhaust system dengan kaidah tersebut kemudian dihitung nilai Teorema Bayes nya dengan mengalihkan Teorema Bayes bobot kepastian dengan Teorema Bayes menjadi:

$$
\begin{aligned}
P[H] 1= & \frac{\mathrm{H} 1}{\mathrm{H} 1+\mathrm{H} 2+\mathrm{H} 3} \\
& =\frac{0,6}{2} \\
& =0,3 \\
P[H] 2= & \frac{\mathrm{H} 2}{\mathrm{H} 1+\mathrm{H} 2+\mathrm{H} 3} \\
& =\frac{0,6}{2} \\
& =0,3 \\
P[H] 3= & \frac{\mathrm{H} 3}{\mathrm{H} 1+\mathrm{H} 2+\mathrm{H} 3} \\
& =\frac{0,8}{2} \\
& =0,4
\end{aligned}
$$

Setelah nilai $\mathrm{P}(\mathrm{Hi})$ diketahui, probabilitas hipotesis $\mathrm{H}$ tanpa memandang Evidence apapun, maka langkah selanjutnya adalah: 


$$
\begin{aligned}
\sum_{k=1}^{n} & =\mathrm{P}(\mathrm{Hi}) * \mathrm{P}(\mathrm{E} \backslash \mathrm{Hi}-\mathrm{n}) \\
\sum_{k=1}^{3} & =0,3 * 0,2+0,3 * 0,2+0,4 * 0,6 \\
& =0,06+0,06+0,24 \\
& =0,36
\end{aligned}
$$

Langkah selanjutnya adalah mencari nilai $\mathrm{P}(\mathrm{HilE})$ atau probabilitas hipotesis Hi benar jika diberikan evidence $\mathrm{E}$.

$$
\begin{aligned}
& \mathrm{P}(H i \mid E)=\frac{P(E \backslash H i) * P(H i)}{\sum_{k=1}^{n} P(E \backslash H i) * P(H i)} \\
& \mathrm{P}(H 1 \mid E)=\frac{0,2 * 0,3}{0,36}=0,1666 \\
& \mathrm{P}(H 2 \mid E)=\frac{0,2 * 0,3}{0,36}=0,1666 \\
& \mathrm{P}(H 3 \mid E)=\frac{0,6 * 0,4}{0,36}=0,6666
\end{aligned}
$$

Setelah seluruh nilai $\mathrm{P}(\mathrm{HilE})$ diketahui, maka jumlahkan seluruh nilai bayesnya dengan rumus sebagai berikut:

$$
\begin{aligned}
\sum_{k=1}^{n} \text { Bayes }= & \text { Bayes } 1+\text { Bayes } 2+\text { Bayes } 3 \\
& =0,1666+0,1666+0,6666 \\
& =0,9998
\end{aligned}
$$

Dari kesimpulan perhitungan diatas maka dapat dipastikan Alat berat (beko) diprediksi mengalami kerusakan air intake and exhaust system dengan nilai 99,98\% maka solusinya adalah periksa kondisi ruang pembakaran sehingga tidak ada kebocoran atau ganti jika perlu. Pengerjaan kerusakan fuel system dengan kaidah tersebut kemudian dihitung nilai Teorema Bayes nya dengan mengalihkan Teorema Bayes bobot kepastian dengan Teorema Bayes menjadi:

$$
\begin{aligned}
P[H] 1= & \frac{\mathrm{H} 1}{\mathrm{H} 1+\mathrm{H} 2+\mathrm{H} 3} \\
& =\frac{0,6}{1,6} \\
& =0,375 \\
P[H] 2= & \frac{\mathrm{H} 2}{\mathrm{H} 1+\mathrm{H} 2+\mathrm{H} 3} \\
& =\frac{0,4}{1,6} \\
& =0,25 \\
P[H] 3= & \frac{\mathrm{H} 3}{\mathrm{H} 1+\mathrm{H} 2+\mathrm{H} 3} \\
& =\frac{0,6}{1,6} \\
& =0,375
\end{aligned}
$$

Setelah nilai $\mathrm{P}(\mathrm{Hi})$ diketahui, probabilitas hipotesis $\mathrm{H}$ tanpa memandang Evidence apapun, maka langkah selanjutnya adalah:

$$
\begin{aligned}
\sum_{k=1}^{n}= & \mathrm{P}(\mathrm{Hi}) * \mathrm{P}(\mathrm{E} \backslash \mathrm{Hi}-\mathrm{n}) \\
\sum_{k=1}^{3}= & 0,375 * 0,2+0,25 * 0,2+0,375 * 0,4 \\
= & 0,075+0,05+0,15 \\
& \quad \text { Muhammad Syahrizal | http://ejurnal.stmik-budidarma.ac.id/index.php/mib | Page | } 31
\end{aligned}
$$




$$
=0,275
$$

Langkah selanjutnya adalah mencari nilai $\mathrm{P}(\mathrm{HilE})$ atau probabilitas hipotesis Hi benar jika diberikan evidence $\mathrm{E}$.

$$
\begin{aligned}
& \mathrm{P}(H i \mid E)=\frac{P(E \backslash H i) * P(H i)}{\sum_{k=1}^{n} P(E \backslash H i) * P(H i)} \\
& \mathrm{P}(H 1 \mid E)=\frac{0,2 * 0,375}{0,275}=0,2727 \\
& \mathrm{P}(H 2 \mid E)=\frac{0,2 * 0,25}{0,275}=0,1818 \\
& \mathrm{P}(H 3 \mid E)=\frac{0,4 * 0,375}{0,275}=0,5454
\end{aligned}
$$

Setelah seluruh nilai $\mathrm{P}(\mathrm{Hi} \mathrm{IE})$ diketahui, maka jumlahkan seluruh nilai bayesnya dengan rumus sebagai berikut:

$$
\begin{aligned}
\sum_{k=1}^{n} \text { Bayes }= & \text { Bayes } 1+\text { Bayes } 2+\text { Bayes } 3 \\
& =0,2727+0,1818+0,5454 \\
& =0,9999
\end{aligned}
$$

Dari kesimpulan perhitungan di atas maka dapat dipastikan Alat berat (beko) diprediksi mengalami kerusakan fuel system dengan nilai $99,99 \%$ maka solusinya adalah ganti injector dengan yang baru.

\section{KESIMPULAN}

Dari pembahasan pada bab-bab sebelumnya, maka penulis mengambil kesimpulan sebagai berikut:

1. Sistem pakar dapat mengidentifikasi kerusakan mesin alat berat (beko) atau excavator, agar dapat memudahkan masyarakat dalam mengetahui gejala-gejala kerusakan yang dimiliki.

2. Metode Teorema Bayes dapat diterapkan pada sistem pakar untuk mengidentifikasi kerusakan mesin alat berat (beko) atau excavator sesuai dengan perhitungannya.

3. Aplikasi telah berhasil dirancang dengan menggunakan bahasa pemrograman Microsoft Visual Basic 2008 dan $M y S Q L$ sebagai pengolah data.

\section{REFERENCES}

[1] Anita Desiani and Muhammad Arhami, Konsep Kecerdasan Buatan, 1st ed., Dhewiberta Hardjono, Ed. Yogyakarta, Indonesia: Penerbit ANDI, 2006

[2] Kusrini, Sistem Pakar Teori dan Aplikasi, 1st ed., fl.Sigit Suyantoro, Ed. Yogyakarta, Indonesia: Penerbit ANDI, 2006.

[3] T. Sutojo, Edy Mulyanto, and Dr. Vincent Suhartono, Kecerdasan Buatan. Yogyakarta, Indonesia: Penerbit ANDI, 2011.

[4] Muhammad Zuchry, "GAYA SILINDER STICK DAN SILINDER BUCKET PADA EXCAVATOR 320 CATERPILLAR AKIBAT GAYA POTONG," Jurnal Mekanikal, vol. 3, no. 2, pp. 293-302, Juli 2012.

[5] Ririn Marlisa, "SISTEM PAKAR MENDIAGNOSA KEGUGURAN PADA IBU HAMIL BERDASARKAN JENIS MAKANAN DENGAN MENGGUNAKAN METODE TEOREMA BAYES," Informasi dan Teknologi Ilmiah, vol. IV, no. 3, pp. 24-32, Oktober 2014.

[6] Russari, Intan;, Sistem Pakar Diagnosa Penyakit Batu Ginjal Menggunakan Teorema Bayes, vol. 3, no. 1, pp. 18-22, Februari 2016.

[7] Jogianto, Hartono;, Analisis dan Desain Sistem Informasi. Yogyakarta, Indonesia: Penerbit Andi, 2005.

[8] Probowo Pudjo Widodo, Herlawati;, Analisis dan Perancangan. Bandung, Indonesia: Penerbit Informatika, 2011.

[9] Rama, Jones; Sistem Informasi Akuntansi. Jakarta, Indonesia: Penerbit Salemba Empat, 2008.

[10] Arif Aditya Primanda, Dasar-Dasar Pemograman Database Desktop Dengan Visual Basic.Net 2008, 1st ed. Jakarta, Indonesia: penerbit PT.Alex Media Komputindo, 2013.

[11] Marsi , Panduan Aplikasi dan Solusi (PAS) Membuat Aplikasi Client Server dengan Visual Basic 2008, 1st ed., Woro Widjaya, Ed. Semarang, Indonesia: Wahana Komputer, 2010.

[12] N. A. Hasibuan, K. Yusmiarti, F. T. Waruwu, and R. Rahim, "Expert systems with genetics probability," Int. J. Res. Sci. Eng., vol. 3, no. 2, pp. 112-116, 2017.

[13] I. Sumatorno, D. Arisandi, A. P. U. Siahaan, and Mesran, "Expert System of Catfish Disease Determinants Using Certainty Factor Method,” Int. J. Recent Trends Eng. Res., vol. 3, no. 8, pp. 202-209, 2017. 
MEDIA INFORMATIKA BUDIDARMA, Vol 2, No 2, April 2018

ISSN 2614-5278 (media cetak)

ISSN 2548-8368 (media online)

Hal 23-33

[14] R. R. Fanny, N. A. Hasibuan, and E. Buulolo, "PERANCANGAN SISTEM PAKAR DIAGNOSA PENYAKIT ASIDOSIS TUBULUS RENALIS MENGGUNAKAN METODE CERTAINTY FACTOR DENGAN PENULUSURAN FORWARD CHAINING," MEDIA Inform. BUDIDARMA, vol. 1, no. 1, Feb. 2017.

[15] R. P. Tanjung and Mesran, "SISTEM PAKAR MENDETEKSI KERUSAKAN MESIN LAS INVERTER DENGAN METODE CERTAINTY FACTOR,” Maj. Ilm. INFOTEK, vol. 2, no. 1, pp. 62-64, 2017.

[16] Yeni Lestari Nasution, M. Mesran, S. Suginam, and F. Fadlina, "SISTEM PAKAR UNTUK MENDIAGNOSIS PENYAKIT TUMOR OTAK MENGGUNAKAN METODE CERTAINTY FACTOR (CF),” J. INFOTEK, vol. 2, no. 1, Feb. 2017.

[17] Verawaty Monica Barus, M. Mesran, S. Suginam, and A. Karim, "SISTEM PAKAR UNTUK MENDIAGNOSIS HAMA PADA TANAMAN JAMBU BIJI MENGGUNAKAN METODE BAYES,” J. INFOTEK, vol. 2, no. 1, Feb. 2017. 